\title{
THE FEATURES OF FORMATION OF SPEECH COMPETENCE OF FUTURE PHILOLOGISTS IN THE EDUCATIONAL PROCESS OF INSTITUTION OF HIGHER EDUCATION
}

\author{
Graduate student Tatiana Vygranka \\ Ukraine, Kharkov, Kharkov National Medical University; \\ Teacher of Kharkov National Medical University
}

DOI: https://doi.org/10.31435/rsglobal_wos/31052019/6502

\section{ARTICLE INFO}

Received: 24 March 2019

Accepted: 22 May 2019

Published: 31 May 2019

\section{KEYWORDS}

speech competence, scientificresearch aspect, methodological preparation, a speech training.

\begin{abstract}
The study was aimed to determine the features of formation of speech competence of future philologists during educational process of institutions of higher education. The ways of teaching and formation speech competence of future philologists are different at institutions of Ukraine. The components of teaching depend of learning plans and educational process at all. The educational situation is in unit of content of activity of students. Therefore successful formations of speech competence depends on detection in professional pedagogical activity that speech, compliances a problem of communication to a form of speech and use of speech means is traced in expedient election of style of speech.
\end{abstract}

Citation: Tatiana Vygranka. (2019) The Features of Formation of Speech Competence of Future Philologists in The Educational Process of Institution of Higher Education. International Academy Journal Web of Scholar. 5(35). doi: 10.31435/rsglobal_wos/31052019/6502

Copyright: (C) 2019 Tatiana Vygranka. This is an open-access article distributed under the terms of the Creative Commons Attribution License (CC BY). The use, distribution or reproduction in other forums is permitted, provided the original author(s) or licensor are credited and that the original publication in this journal is cited, in accordance with accepted academic practice. No use, distribution or reproduction is permitted which does not comply with these terms.

Introduction. Training of future philologists in institutions of higher education is carried out on the basis of normative documents and laws: The law of Ukraine of 01.07.2014 No 1556-VII "About the Higher Education", standards and recommendations about quality assurance in the European space of the higher education (ESG), International Standard Classification of Education (ISCED 2011), ISCED Fields of Education and Training 2013 (ISCED-F 2013), the Standard of the Higher Education.

According to state standard of the higher education in Ukraine in "philology", training of future philologists is based on application competence in study, and "the system of providing with institution of higher education of quality of educational activity and quality of the higher education (the system of internal quality assurance) on representation of institution of higher education is estimated by National agency on ensuring quality of the higher education or independent institutions of estimation and ensuring quality of the higher education accredited by it regarding its compliance to requirements to the system of ensuring quality of the higher education that are approved by National agency on ensuring quality of the higher education, and the international standards and recommendations about ensuring quality of the higher education" [1, 2, 3, 4].

In the majority of institutions of the higher education in Ukraine future philologists after the end of training gain diplomas with qualification not only of the philologist, but also the teacher that in turn, expands opportunities for employment of graduates and their self-realization.

Having analysed pedagogical researches on a problem of features of training of future philologists in institutions of higher education, we can claim that vocational training of such experts has the structure and separate features of its application.

According to the researcher A. V. Lypchanko-Kovachyk such structure consists of standard and variable parts. The first - includes research, psychology and pedagogical and theoretical-methodological preparation, the second - vocational training [8]. The researcher V.S. Zhuravskyi notes that a variable part 
consists of the disciplines recommended in standard, but the right to choose and enter them into educational process remains behind institution of higher education. So variable preparation includes disciplines which form and expand scientific awareness of future philologists in general, paying attention to their personal interests. The component of vocational training - is limited to the standard of training of future pedagogical workers of a philological profile that is based on simultaneous are entered disciplines of theoretical, methodological, psychology and pedagogical and research preparation [6].

During theoretical-methodological preparation in future philologists knowledge, abilities, skills are formed, that is future experts gain knowledge of pedagogical and philological orientations. Most of researchers, in particular V.A. Slastenin consider that a basis of vocational training of future philologists psychological and pedagogical orientation. It contributes to the development of creative potential, pedagogical consciousness of future philologists that in the future will be able to find the reflection in professional and scientific and pedagogical activity [15]. The scientific-research aspect of preparation provides understanding and acquisitions of professional competence of future philologists, their knowledge on teaching languages, means and techniques of training of disciplines of a philological profile.

In Ukraine training of future philologists is carried out at the classical, pedagogical, state universities and also at philological faculties and faculties of foreign languages of other institutions of the higher education of III and IV levels of accreditation.

Linguistic disciplines, taught in institutions of education aim not only to deepen knowledge of future philologists of language, "to estimate historical properties and the latest developments philological sciences, to characterize theoretical and practical aspects concrete philological the industries, to show profound knowledge of the specialization chosen philological" [2], but also to create a social-linguistic the personality. We consider that the level of speech competence is the key to such personality.

Research results. Speech competence is one of key for future philologists in their professional and pedagogical activity. The modern expert of a philological profile has to possess not only knowledge and abilities of the specialty, but also mother the developed ability to reproduction of speech processes. Speech competence consists of several structural components: practical, motivational, informative. Structurally component structure of speech competence provides successful use of professional potential in educational process.

Training programs which are used in educational process of institution of higher education of Ukraine are created according to state standard of the higher education of Ukraine and also internal university resolutions. So, to special disciplines include disciplines in a course of training of future philologists that offer other departments and divisions of the university. To the theoretical and methodical part of preparation include disciplines of departments of philosophy, history, to informatics, sociology, foreign languages, etc. The psychological and pedagogical part of preparation is supplemented by departments pedagogics, psychology, to sociology, etc. The scientificresearchering part of preparation is provided by departments the professional direction of philologists (linguistics, philology, the translation, etc.) and scientific student circles which operate on an extent of academic year at the university. The special popularity is gained by interfaculty disciplines that is about are have to be included in educational process, respectively in training programs, or optional, that is at the choice of students.

Besides, the researcher A. V. Lypchanko-Kovachyk, based on educational professional the program of training of philologists of bachelors, notes that teaching disciplines has to be taking into account European integration, providing modernization of content of preparation; observance of one system of standards of preparation; Use of the didactic principles of a humanization, differentiation with the stage-by-stage introduction of knowledge on theoretical preparation and formation of practical skills of speech activity of future philologists that in turn is a basis of formation of speech competence; Use of accurate methods of quality check of professional education.

At most the universities of Ukraine a problem of formation of speech competence it is assigned to departments of pedagogics. To some extent, it depends on methodological preparation, the purpose of pedagogical disciplines not only to acquaint and teach pedagogical technologies which are used in educational process, but also to teach pedagogical skill at the heart of which it is assigned formations of speech competence, in particular, of future philologists.

At T.G. Shevchenko Luhansk National University of formation of speech competence of future philologists it is carried out not only on the occupations on vocational training, but also disciplines taught by department of pedagogics. The course "pedagogics" for philologists provides application of didactic conditions, the most effective for formation of speech competence of future philologists. 
L.G. Vyshnyakova scientist claims that the basic principle of studying of language disciplines - the principle of communicative orientation. It is capable to influence formation of professional and speech competences of future philologists and provides performance of didactic conditions and tasks: Selection of a situation, participation of everyone in communication, communicativeness of tasks, recurrence and novelty, favorable conditions for communication [5].

V.M. Miroshnichenko notes that formation speech competence (identifies with communicative) of future philologists depends on use in didactic process of interactive technologies which are aimed at the development of creative, professional, communicative activity of future philologists. Also the researcher claims that speech activity of future philologists needs formation of language knowledge, skills of communication. Therefore successful formations of speech competence depends on detection in professional pedagogical activity that speech, compliances a problem of communication to a form of speech and use of speech means is traced in expedient election of style [9].

O.I. Pometun considers that he is one of a type of active training interactive as all participants are involved in didactic process and are equal. Interactive training is constructed on interactive technologies which in turn are divided into imitating and no-imitating. The first of them consist of didactic game technologies that are designed to form language skills according to professionally pedagogical situations that imitated; The Basis of the last is dialogue technologies that cover individual ability of students to communication processes. The no-imitating technologies are interactive lecture, technologies of cooperative training, discussion [9]. Scientists consider that noimitating interactive technologies are priority in formation of professional and speech competences of future philologists. During their realization there is a formation of speech abilities, depending on a modality of a speech situation, development emotionally psychological balances to this or that communicative situation, cognitive development in communication.

On the basis of the considered researches, it is possible to claim that broadcasting the competence of future philologists is based on the principle of speech orientation, the training realized by means of interactive methods and technologies of training.

Researcher of G. Rikheit in the context of two structures considers the concept "communicative competence" (speech competence): internal and external. The internal structure is guided by such concepts as efficiency, expediency that are outlined result of speech activity respectively to application in a real speech situation. The external component includes concepts: practical application, abilities, abilities, knowledge, motivation, emotion, behavior [13].

The researcher A. Krayevskaya notes that "communicative (broadcasting) the competence effectively develops in conditions of situation, speech and cogitative activity, functionality, individualization, novelty and cross-cultural dialogue" [Krayevskaya, page 59]. So, A. Krayevskaya offers use of a psychological training in the course of formation of speech (communicative) competence of future philologists as it is a peculiar technology of influence on future philologist and development of communicative interaction with other participants speech communicative process. The psychological training is based on problems of the personal focused training. That is exercises are constructed in such a way that in the course of their performance occurs mastering language material and means of communication. In particular, this method are considered for formation of speech competence of future philologists of a foreign language. Therefore the following technicians use: active hearing (there is a formation of abilities broadcasting, understanding - drawing up questions and the equipment a talk, interpretation, rephrasing and the translation. The main aspect of a speech training is holding a conversation. For E.V. Sidorenko considers that such conversation is characterized small about "volume and it is directed to vitally household subjects. The main objective of such conversation is in creating a comfortable psychological situation with positive and trustful the atmosphere. Such atmosphere will promote easy, creative and effective formations of speech competence of future philologists. In the course of educational training of future philologists, introduction of the psychological-comunicating techniques, in opinion, O. Kraevska, will promote successful formation of their speech competence [Krayevskaya, page 58 61].

V.M. Zinchenko interpretations of speech competence abilities to expediently use language means for formation of statements and texts according to rules of an oral and written language. So, the researcher considers formation of speech competence of future experts of a philological profile in use of system approach of training as one of fixed assets of a technique of scientific knowledge. The principle of sitsematichnost includes a thinking technology that is implemented in contact with all levels of language. System approach is based on modeling of the language system consisting of the following elements: purpose, contents, didactic forms, methods, means, results of training. Acquisition 
of speech abilities and knowledge is a consequence of such approach in training that is powerful for the solution of various communicative tasks in practical professional activity. Implementation of vocational training of future philologists takes place in stage-by-stage the sequences: studying of the basic scientific concepts of language, performance of didactic exercises, use of the developed speech competence with other acquired components of professional activity [16].

A. Semenog considers formations of speech competence of future philologists through a prism of professional competence with application of a complete system of training. Such system of training has to have base, depth, intellectual and practical orientation, is personal - and professionally approximate character" [14].

N.N. Romanova claims that formation of speech competence depends on free possession of oral and written broadcasting, understanding broadcasting in different groups of exchange of information, ability to produce and understand broadcasting in any style [7].

A.I. Kuzminskyi in the context of cognitive communicative approach considers formations of speech competence of future philologists of foreign languages through the system of interaction of different types of speech activity: reading, audition, speaking and writing.

Reading develops on the basis of oral speech. In the course of reading future philologists form lexical, grammatical, cognitive skills [7].

Audition depends on speech activity - ability of fast simultaneous perception and identification of phonetic filling and application lexical-grammatical skills. In process audition the ability of perception, distinction of a stream of broadcasting, systematization of semantic meanings, definition of a subject and purpose the message, the perceptive understanding of information, treatment the message are formed [7].

Speaking is realization of speech skills. Execution of a statement according to linguisticcultural environments it is carried out by means of phonologic, grammatical and lexical skills. Thus, the high level of formation of speech skills allows the speaker to orient on contents of a statement, but not on configuration of a form of the last [7]. On occupations of foreign languages future philologists study in the course of speaking to make one complete phrase, to combine different phrases, to transform, expand, supplement language samples according to the purposes are already acquired and communication conditions, freely to state the thoughts, to discuss the facts and events, to open cause and effect contacts of events and the phenomena " [7].

Formations of abilities of the letter for future philologists becomes guarantee of successful formation of written competence. In turn, to abilities which belong to them ability to retell the matter written the text according to set subjects, to competently organize the text from the point of view of its composite structure, it is correct to select language means and to choose style of the work depending on the writing purpose.

\section{Conclusions.}

1. The educational situation is in unit of content of activity of students.

2. The ways of formation speech competence of future of philologists are different and require realization of some components of standard and variable parts. The first - includes research, psychology and pedagogical and theoretical-methodological preparation, the second - vocational training.

\section{REFERENCES}

1. Закон України від 01.07.2014 № 1556-VII «Про вищу освіту». - http://zakon4.rada.gov.ua/laws/show/1556-18.

2. Стандарти і рекомендації щодо забезпечення якості в Свропейському просторі вищої освіти (ESG). - K.: TOВ «ЦС», 2015. 32. - http://ihed.org.ua/images/pdf/standards-and-guidelines_for_qa_in_the_ehea_2015.pdf;

3. International Standard Classification of Education (ISCED 2011). - Montreal: UNESCO Institute for Statistics, 2012. - http://www.uis.unesco.org/education/documents/isced-2011-en.pdf.

4. ISCED Fields of Education and Training 2013 (ISCED-F 2013). - Montreal: UNESCO Institute for Statistics, 2014. - http://www.uis.unesco.org/Education/Documents/isced-fields-of-education-training-2013.pdf.

5. Вишнякова Л. Г. Использование деловых игр в преподавании русского языка как иностранного/ Лариса Георгиевна Вишнякова. - М.: Изд-во Моск. ун-та, 1987.107.

6. Журавський В.С. Болонський процес: головні принципи входження в Свропейський простір вищої освіти. - К.: Політехніка. 2003. 200с.

7. Кузьмінський А.І. Методика навчання англійської мови в аспекті комунікативно-когнітивного підходу. Черкаси: Вид-во ЧНУ ім. Б. Хмельницького, 2011. 316.

8. Липчанко-Ковачик О. В. Особливості підготовки майбутніх бакалаврів-філологів у вищих навчальних закладах. Збірник наукових праць [Херсонського державного університету]. Педагогічні науки. 2017. Вип.76(2). 81-85. 
9. Мірошниченко В. М. Професійна підготовка майбутніх філологів засобами інтерактивних технологій. Випуск 58’2017 Серія 5. Педагогічні науки: реалії та перспективи. Науковий часопис НПУ імені М. П. Драгоманова. 2017. 105-112.

10. Остапенко Н. М. Теорія і практика формування лінгводидактичних компетентностей у студентів філологічних факультетів ВНЗ. Черкаси: видавець Чабаненко Ю., 2008. 330.

11. Педагогика: учеб. пособ. для студ. пед. учеб. заведений / под ред. В. А. Сластенина. - М.: ШколаПресс, 1997. 512.

12. Пометун О. І. Інтерактивні методики та система навчання. - К.: “Шкільний Світ”, 2007. 112.

13. Rickheit G. Handbook of Communicative Competence / Gert Rickheit, Hans Srohner. - Gottingen: Hubert \& Co., 2008. 561.

14. Семеног О. М. Професійна підготовка майбутніх учителів української мови і літератури: монографія. Суми: Мрія-1, 2005. 404.

15. Сластенин В. А. Профессионализм педагога: акмеологический аспект. Педагогическое образование и наука. - М.: 2002. №4. 6-9.

16. Автореферат http://kubg.edu.ua/images/stories/Departaments/apirantam/Avtoreferat/K.26.133.05/VM_Zinchen ko_avtoreferat.pdf 